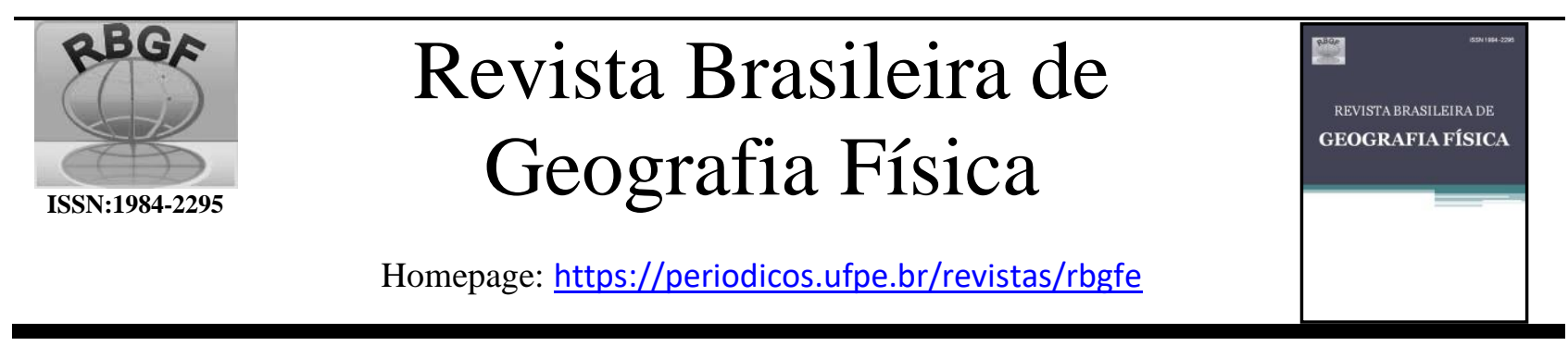

\title{
Análise Geomorfológica da Transição Cuestas-Depressão Periférica: A Alta Bacia do Rio Passa Cinco(SP) como estudo de caso
}

\author{
Tissiana de Almeida de Souza ${ }^{1}$, Rafael Vilela de Andrade ${ }^{2}$, Cenira Maria Lupinacci ${ }^{3}$
}

\begin{abstract}
1 Pós-Doutorado em Geografia, UNESP, Campus de Rio Claro, Avenida 24A n. 1515, CEP 13506900, Rio Claro, São Paulo, (19) 35269331, tissisouza@gmail.com. ${ }^{2}$ Discente de graduação em Geografia, UNESP, Campus de Rio Claro, Avenida 24A n. 1515, CEP 13506900, Rio Claro, São Paulo, (19) 35269331, rafael.vadr@ gmail.com. ${ }^{3}$ Professora Doutora, UNESP, Campus de Rio Claro, Avenida 24A n. 1515, CEP 13506900, Rio Claro, São Paulo, (19) 35269331, cenira.lupinacci@ unesp.br.
\end{abstract}

Artigo recebido em 19/04/2019 e aceito em 01/04/2020

\section{RES UM O}

O relevo paulista é marcado pela presença de extensa linha de cuestas cuja origem ainda hoje suscita discussões. Assim, o objetivo deste estudo foi analisar as características morfoestruturais da Alta Bacia do Rio Passa Cinco, situada em setor de transição Cuestas - Depressão Periférica, a qual se constitui em exemplo significativo da dinâmica deste tipo de relevo visto a complexidade de formas existentes, que incluem extenso front contínuo e morros testemunhos de variados tamanhos, com características e extensões diversificadas. Os dados para avaliar a área de estudo foram obtidos através da interpretação integrada das cartas Geomorfológica, Clinográfica, de Densidade de Drenagem, de Profundidade de Dissecação e de Lineamentos, na escala 1:50.000. Além da circundesnudação, considerado o fator clássico de origem e desenvolvimento destes dois macrocompartimentos do relevo, fatores tectônicos também necessitam ser avaliados para o entendimento das formas de relevo. Esses fatores são responsáveis pela aceleração da ação erosiva dos cursos fluviais em alguns setores, colaborando com a circundesnudação, assim como pela diferenciação das características do Front Cuestiforme e dos morros testemunhos. Assim, entende-se que os procedimentos técnicos permitiram obter dados que demonstram a complexidade que envolve a elaboração do relevo nesse setor de transição e que são passíveis de serem estendidos a outros setores do interior do Estado de São Paulo caracterizados por tais relevos.

Palavras-chave:Densidade de drenagem, profundidade de drenagem, lineamentos, declividade.

\section{Geomorphological Analysis of the Cuesta-Peripheral Depression: Case study of the Passa Cinco River watershed}

\begin{abstract}
A B S T R A C T
The relief of São Paulo is characterized by the presence of long cuesta, whose origin causes discussion until the present day. Thus, the objective of this research is to analyze the morphostructural characteristics of the Passa Cinco River watershed, situated at transition zone of Cuestas-Peripheral Depression, constituting significative example of this relief system, taking in consideration the complexity of existing forms, that include extense continuous cuesta scarp and buttes of different sizes, extensions and characteristics. The data to analyze the study area were obtained through the integrated interpretation of the Geomorphological, Declivity, Drainage Density, Depth of Drainage and Lineation maps, in 1:50.000 scale. Beyond circumdenudation, considered the classic process of origin of these two relief macrocompartments, tectonic factors also need to be evaluated in order to have a better understanding of these relief forms. These factors are responsible for the acceleration of erosive processes promoted by river courses in some sectors, collaborating with the circumdenudation process, as with the local variation of the Cuesta Front and buttes. Thus, it is understood that the technical procedures allowed to obtain data that demonstrate the complexity involved in the elaboration of the relief in this transition sector, being able to be extended to others areas of the interior of the state of São Paulo with this same relief characteristics.
\end{abstract}

Keywords: drainage density; depth of drainage; lineation; declivity.

\section{Introdução}

O interior do Estado de São Paulo é caracterizado pela presença de um relevo suavizado de colinas, que aproximadamente em sua porção centro-ocidental é interrompido por uma linha sinuosa de escarpas talhadas em estruturas monoclinais, conhecidas como Cuestas 
Basálticas, cuja manutenção está associada à ocorrência de derrames basálticos.

O desenvolvimento e a evolução do macrocompartimento geomorfológico das Cuestas Basálticas está diretamente relacionado com a formação de outra grande sessão do relevo do Estado de São Paulo: a Depressão Periférica.

Segundo Pinheiro e Queiroz Neto (2015), o entendimento da origem das Cuestas Basálticas e da Depressão Periférica Paulista constitui-se em um dos principais problemas da Geomorfologia do Estado de São Paulo. A interpretação mais aceita, de acordo com os autores, é que a erosão diferencial tenha sido a grande atividade responsável pela gênese destes dois macrocompartimentos.

Para Almeida (1949), a ação erosiva da densa rede de drenagem, aliada à atual condição climática quente e úmida, foram as responsáveis pelo processo geomorfológico evolutivo das Cuestas. Com relação à Depressão Periférica, esta teria se formado pela erosão diferencial, juntamente ao trabalho dos cursos d'água com cabeceiras situadas no Planalto Cristalino.

Ab’Saber (1969) classificou a Depressão Periférica Paulista como um compartimento topográfico predominantemente originário por circundesnudação, resultante de uma longa fase erosiva ocorrida entre o Eoceno e o Plioceno, que teria provocado escavação e rebaixamento através de fenômenos denudacionais de alta complexidade, e por último, pediplanação intertropical extensiva. No entanto, apesar de considerar a circundesnudação como o principal processo evolutivo da área, o autor destacou a necessidade de buscar informações relativas à questão genética do relevo ligada também ao Quaternário.

Penteado (1976) ao estudar a gênese e evolução do relevo no setor centro-ocidental da Depressão Periférica e das Cuestas, busca integrar evidências de atividades tectônicas e da atuação morfoclimática durante o Quaternário, sobretudo, aquelas ligadas aos fatores de reativação tectônica, como o traçado e inflexões de drenagens da Depressão Periférica e o aspecto trapezoidal e triangular das escarpas das Cuesta e dos Morros Testemunhos.

Vieira (1981), ao tratar sobre uma hipótese para a origem da Depressão Periférica Paulista, afirma que esta apresenta gênese tectônico-erosiva. Desde o início da separação entre Brasil e África, com auge durante o Cenozoico, a Bacia Sedimentar do Paraná passou por um processo de tectonismo que resultou em soerguimento da região continental emersa. O acúmulo de magma durante o Jurássico e o Cretáceo teria criado um desequilíbrio isostático, que associado com o contínuo preenchimento da Bacia do Paraná por sedimentos, teria resultado em uma reativação de extensas e antigas linhas de fraqueza durante o Terciário, originando grandes falhamentos.

O Projeto RADAMBRASIL (1983) considera a Depressão Periférica como uma área de gênese e de evolução complexas, devido ao fato de ser produto da atuação conjunta entre fatores de natureza tectônica/estrutural e de alterações climáticas.

Facincani (2000) investigou as estruturas neotectônicas na região das Cuestas Basálticas e da Depressão Periférica na região entre Rio Claro, São Carlos e Piracicaba (SP). Para a autora, um primeiro evento tectônico distensivo (pré-atual) estaria relacionado à deposição de coberturas terciárias, enquanto um segundo evento tectônico transcorrente (atual), relacionado com a rotação da Placa Sul-Americana para oeste, interferiu nos depósitos coluvionares modernos, na presença de facetas triangulares e trapezoidais na área, na ocorrência de shutter ridges, de capturas e cotovelos de drenagem e assimetria de vales e terraços.

Godoy et al. (2006) afirmam que a borda leste da Bacia Sedimentar do Paraná, na qual está localizada a Depressão Periférica Paulista, apresenta influências tectônicas desde a ruptura do Gondwana, durante o Mesozoico-Cenozoico. Após a abertura do Oceano Atlântico, a Bacia do Paraná continuou a apresentar evolução tectônica, através da reativação de estruturas do embasamento adjacente a pacote sedimentar. Consequentemente, as camadas constituintes da bacia sedimentar sofreram deslocamentos, gerando grandes alinhamentos relacionados a zonas de falha, diques, sills de diabásio e altos estruturais.

$$
\text { Pinheiro e Queiroz Neto (2015) }
$$

destacaram que, além dos processos de circundesnudação, as áreas de Cuestas e da Depressão Periférica na região de São Pedro (SP) apresentam aspectos de controle tectônico na configuração do relevo, como as características geométricas da Serra Geral (Cuestas) e o traçado retilíneo das drenagens.

Pinheiro e Queiroz Neto (2015) analisaram a influência dos movimentos tectônicos recentes na região da Serra de São Pedro e do baixo curso do Rio Piracicaba (SP), procurando compreender a relação entre gênese das formas de relevo e o regime de neotectônica existente desde o Neogeno. Os autores afirmam que a configuração do relevo é originada das diferenças de litologia regional e da influência de estruturas tectônicas, que condicionam sobretudo a rede de drenagem. A atividade neotectônica, por sua vez, é passível de identificação nas áreas em que os falhamentos 
truncam depósitos quaternários, nas deformidades dos perfis longitudinais dos canais fluviais, na formação e degradação de trechos dos terraços fluviais da margem direita do Rio Piracicaba, na ascensão e subsidência lenta de blocos.

Aguilar e Cunha (2015) analisaram a influência tectônica sobre um conjunto de morros testemunhos na Serra da Atalaia, região de Analândia e Corumbataí (SP), a partir de uma análise morfoestrutural. Para os autores, os processos tectônicos locais ocorridos no período pós-cretáceo resultaram no soerguimento da estrutura local, que apresenta altimetrias acima das cornijas que estão situadas no entorno. Outro fato constatado pelos autores é que a direção dos lineamentos mais significativos da área de estudo coincide com afloramentos de diques de diabásio da Serra da Atalaia.

Stefanuto e Lupinacci (2016) abordaram aspectos morfoestruturais da região de contato entre as Cuestas Basálticas e a Depressão Periférica Paulista na Serra do Cuscuzeiro, em Analândia (SP). Através do cruzamento de cartas temáticas, os autores detectaram peculiaridades da ação da drenagem sobre o setor de front cuestiforme, que se relacionam com a espessura do estrato basáltico e as diferenças de declividades.

Os fatos discorridos mostram a necessidade de considerar não apenas os processos de circundesnudação como os responsáveis pela gênese e evolução do relevo nas áreas da Depressão Periférica Paulista e Cuestas Basálticas, como também a análise da influência de ações tectônicas na esculturação das formas do relevo.

Diante das considerações apresentadas, o objetivo deste trabalho foi analisar as características morfoestruturais da Alta Bacia do Rio Passa Cinco, situada nos municípios de Itirapina e de Ipeúna, na porção centro-leste do Estado de São Paulo, em setor de transição Cuestas - Depressão Periférica. Considera-se que essa área constitui-se em exemplo significativo da dinâmica do relevo de cuestas do interior do Estado de São Paulo visto a complexidade de formas, que incluem extenso front contínuo e morros testemunhos de variados tamanhos, com características e extensões diversificadas. Assim, o estudo apresentado, ao ser correlacionado a outros, pode auxiliar na elucidação da dinâmica dessas características geomorfológicas do interior paulista.

Os dados para avaliar a área de estudo foram obtidos através da interpretação integrada de produtos cartográficos - Carta Geomorfológica, Clinográfica, de Densidade de Drenagem, de Profundidade de Dissecação e de Lineamentos - na escala 1:50.000, visando o entendimento dos processos geomorfológicos ocorrentes e possíveis influências tectônicas na evolução do relevo da área de estudo.

A Carta Geomorfológica foi elaborada com base na legenda de Tricart (1965) e de Verstappen e Zuidam (1975) adaptados ao ambiente do software ArcGIS®. As Cartas de Densidade de Drenagem e de Profundidade de Dissecação foram produzidas a partir da adequação para meio digital da técnica de Hubp (1988). A Carta de Lineamentos apresenta dados compilados de Facincani (2000) e complementados por Andrade (2018). Por último, a Carta Clinográfica foi preparada a partir dos procedimentos técnicos propostos por De Biasi (1992).

\section{Material e métodos}

Área de estudo

A Alta Bacia do Rio Passa Cinco apresenta aproximadamente $288 \mathrm{~km}^{2}$ de área, se estendendo da nascente do Rio Passa Cinco, localizada na Serra da Cachoeira, município de Itirapina, até sua confluência com o Rio de Cabeça, situada no município de Ipeúna.

As altitudes da área de estudo variam entre $520 \mathrm{~m}$, nas proximidades com o Rio da Cabeça, a $1.060 \mathrm{~m}$, no Reverso da Cuesta (Figura 1). O front cuestiforme está situado entre 740 e $980 \mathrm{~m}$, apresentando desníveis de mais de $200 \mathrm{~m}$.

Conforme o contexto geomorfológico regional, a Alta Bacia do Rio Passa Cinco está posicionada na transição entre as Cuestas Basálticas e a Depressão Periférica Paulista.

$\mathrm{Na}$ área do Reverso predominam colinas de topos tabulares e colinas de topos convexos. $\mathrm{Na}$ Depressão Periférica, os morros testemunhos sobressaem topograficamente das áreas de entorno, que são dominadas por colinas amplas e colinas médias, morrotes alongados e espigões (IPT, 1981b).

Estes dois grandes compartimentos e suas formas de relevo características desenvolveram-se sobre camadas homoclinais de litologias diversificadas.

No setor sudeste da Alta Bacia do Rio Passa Cinco, próximo à confluência com o Rio da Cabeça, constata-se a ocorrência da Formação Tatuí, constituída predominantemente por siltitos (IPT, 1981a). Adjacente a este estrato, ainda no setor sudeste da área de estudo, aflora a Formação Irati, que apresenta folhelhos e calcários (Perrota et al., 2005). Em contato direto com essa encontra-se a Formação Corumbataí, composta por folhelhos e argilitos.

A litologia predominante na área de estudo é a Formação Piramboia, caracterizada pela 
ocorrência de arenitos médios a finos (IPT, 1981a; Perrotta et al., 2005).

A Formação Botucatu, também constituída por arenitos, faz seu contato com os derrames basálticos cretáceos (IPT, 1981a) da Formação Serra Geral por interestratificação. A Serra Geral, que congrega tais derrames, constitui-se no estrato de maior resistência aos processos erosivos, conservando o front das Cuestas e a cornija dos morros testemunhos.

No reverso da cuesta aflora a Formação Itaqueri, constituída por arenitos com cimento argiloso, folhelhos e conglomerados (Perrotta et al., 2005).

Coberturas Indiferenciadas Neógenas constituídas por areias e cascalhos são localmente encontradas no trecho sudeste da alta bacia, e nos arredores do Córrego Monjolo Grande.

A diversidade de litologias tem influência direta nos diferentes tipos de solos. Os Argissolos (IAC, 1981, 2014) predominam no trecho da Alta Bacia situado na Depressão Periférica Paulista e são originados a partir dos materiais disponíveis das Formações Piramboia, Corumbataí, Irati e Tatuí, no trecho central e sudeste da área de estudo.

Com relação aos Latossolos, são encontrados dois tipos: o Vermelho e o VermelhoAmarelo (IAC, 1981, 2014). O primeiro ocorre pontualmente nos setores sul, sudeste e norte da área de pesquisa. O Latossolo Vermelho-Amarelo se desenvolve no Reverso, sobre depósitos da Formação Itaqueri. Na Depressão Periférica, ocorre com maior expressividade sobre materiais relacionados à Formação Piramboia. No setor sudeste, está associado às Coberturas Indiferenciadas.

O Nitossolo Vermelho (IAC, 1981, 2014) aparece pontualmente ao sul e ao leste da área de estudo, nos arredores do Front Cuestiforme. Os Neossolos Litólicos (IAC, 1981, 2014) são espacialmente correspondentes aos basaltos da Formação Serra Geral que sustentam as escarpas da Cuesta Basáltica. Já os Neossolos Quartzarênicos (IAC, 1981, 2014), estão associados aos arenitos das Formações Piramboia e Botucatu e a Coberturas Indiferenciadas da Depressão Periférica.

As características dos solos se refletem nos tipos de uso e cobertura da terra na área de estudo.

No Reverso ocorrem usos diversificados, com presença de plantações de cana-de-açúcar, pastagens, silvicultura (Valente, 2001) e de floresta nativa.
O front da Cuesta e os morros testemunhos são caracterizados por manchas contínuas de cobertura arbórea (silvicultura e mata). Segundo Azevedo (2003), no sopé da Cuesta ocorrem pastagens e cana-de-açúcar.

Conforme Valente (2001), culturas anuais, como mandioca, milho, sorgo, entre outros, estão distribuídas por toda a Alta Bacia do Rio Passa Cinco, com exceção dos morros testemunhos.

Manchas expressivas de plantio de canade-açúcar são encontradas próximo à confluência com o Rio da Cabeça e nos arredores de Ipeúna, no interflúvio entre o Ribeirão João Pinto e o Córrego dos Sinos e nas adjacências do Córrego do Cantagalo.

Na Depressão Periférica, ocorrem áreas de pastagens nos interflúvios de córregos e ribeirões afluentes do Rio Passa Cinco, com manchas destacadas ao longo do Rio Pirapitinga. Ainda, na área estudada, registra-se a presença de matas ciliares bem demarcadas ao longo das drenagens.

As características vegetacionais e pedológicas da área de estudo são influenciadas diretamente pelo clima regional. A Alta Bacia do Rio Passa Cinco está inserida, conforme a Classificação de Köppen, em zona climática do tipo $C w a$, caracterizada por inverno seco, verão chuvoso e mês mais quente com temperatura média acima de $22^{\circ} \mathrm{C}$ (CEPAGRI, 2017).

\section{Produtos Cartográficos}

As cartas Geomorfológica, Clinográfica, de Profundidade de Dissecação, de Densidade de Drenagem e de Lineamentos foram elaboradas com o apoio da Base Cartográfica em escala 1:50.000, que foi organizada a partir das Folhas Topográficas Itirapina (SF-23-M-I-3) e Rio Claro (SF-23-M-I$4)$.

Os produtos cartográficos foram elaborados através da aplicação e da adaptação de técnicas específicas ao ambiente digital do software ArcGIS®.

A Carta Geomorfológica foi produzida através da interpretação visual de imagens tridimensionais com óculos 3D, elaboradas a partir dos procedimentos propostos por Souza e Oliveira (2012). Estas imagens em três dimensões foram preparadas após a digitalização de pares estereoscópicos de fotografias aéreas em escala 1:40.000, ano de 1988, que posteriormente foram georreferenciadas de acordo com a Base Cartográfica na escala 1:50.000. 


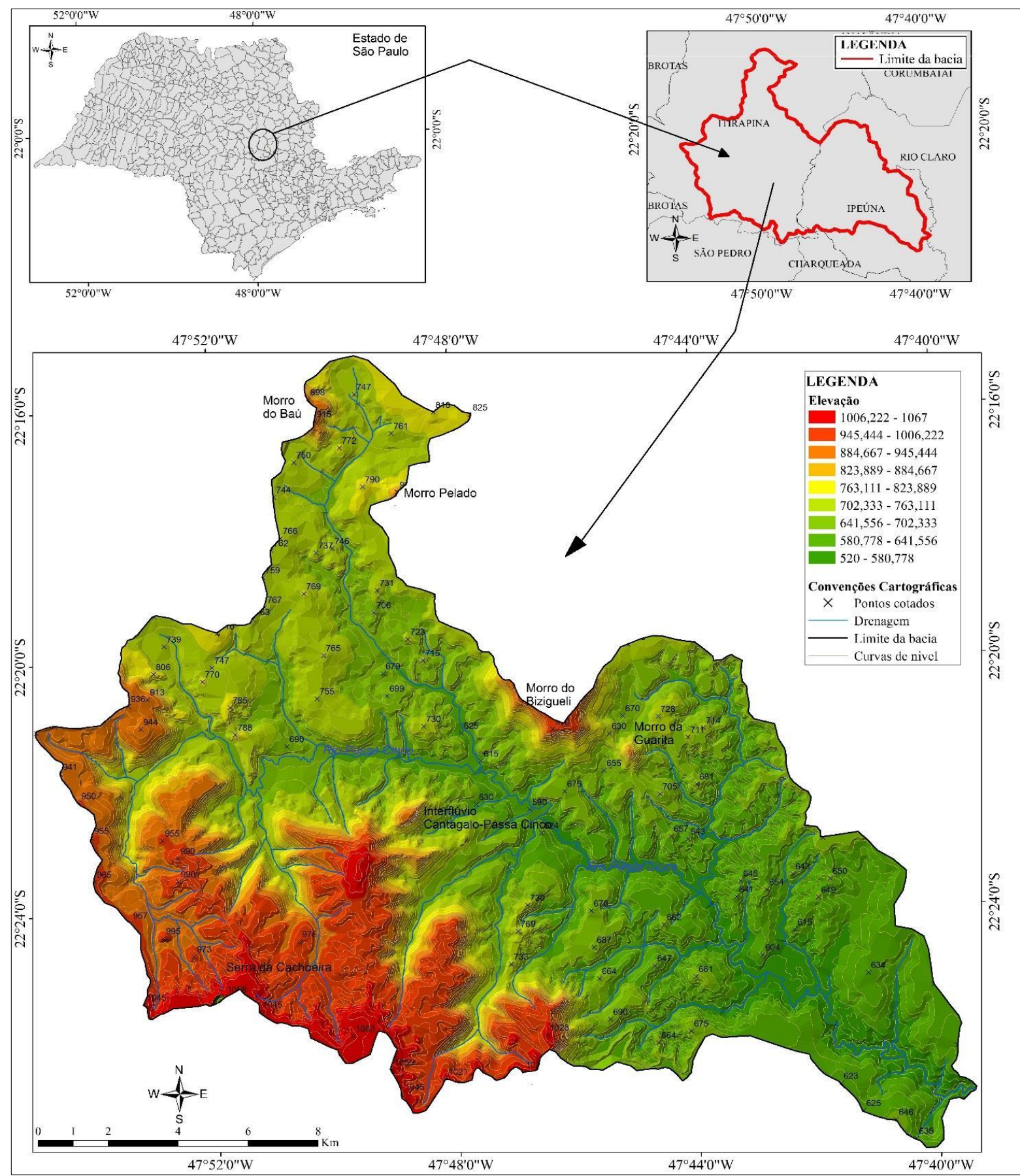

Figura 1. Localização da área de estudo e características altimétricas.

As simbologias alusivas às formas de relevo foram adaptadas de Tricart (1965) e de Verstappen e Zuidam (1975). Ambos os procedimentos técnicos enfatizam que, devido à complexidade dos fatos geomorfológicos, as legendas são abertas e podem apresentar adaptações e inserções de novos símbolos.

Tricart (1965) propõe a interpretação geomorfológica a partir de quatro dados distintos:

- Dados morfométricos: estão presentes nas cartas topográficas (curvas de nível, pontos cotados e drenagens);

- Dados morfográficos: simbologias que constituem a legenda geomorfológica;
- Dados morfogenéticos: as simbologias devem permitir a compreensão direta da gênese das formas de relevo;

- Dados cronológicos: necessários para entender a associação entre as feições geomorfológicas, seu desenvolvimento atual e possíveis oscilações climáticas da área de estudo.

Verstappen e Zuidam (1975), por sua vez, destacam que a interpretação de fotografias aéreas, complementadas por trabalhos de campo e análises laboratoriais, pode resultar em um produto cartográfico detalhado e preciso sobre as características geomorfológicas de uma área de pesquisa. 
Os autores propuseram o Sistema ITC, o qual contempla os aspectos morfográficos, morfométricos, morfogenéticos e morfocronológicos para a elaboração de uma Carta Geomorfológica.

Considerando a proposta desses autores, as simbologias referentes às formas de relevo mapeadas para a Alta Bacia do Rio Passa Cinco
(Quadro 1) foram elaboradas conforme os procedimentos descritos por Paschoal et al. (2010), na qual a primeira etapa consiste na criação de shapefiles no ArcCatalog ${ }^{\mathrm{TM}} \mathrm{e}$, em seguida, a edição de cada uma das simbologias no ambiente do $\operatorname{ArcMap}^{\mathrm{TM}}$.

Quadro 1. Formas do relevo mapeadas para a área de estudo com suas respectivas origens bibliográficas e representação.

\begin{tabular}{|c|c|c|c|}
\hline $\begin{array}{c}\text { FORMAS DE } \\
\text { ORIGEM } \\
\text { ESTRUTURAL }\end{array}$ & Cuesta & $\begin{array}{l}\text { Tricart (1965); } \\
\text { Verstappen e Zuidam (1975) }\end{array}$ & monen \\
\hline \multirow{12}{*}{$\begin{array}{c}\text { FORMAS DE } \\
\text { VERTENTES E } \\
\text { INTERFLUVIOS }\end{array}$} & Vertente côncava & \multirow{5}{*}{ Verstappen e Zuidam (1975) } & עy \\
\hline & Vertente convexa & & 4 \\
\hline & Vertente retilínea & & - \\
\hline & Vertente irregular & & 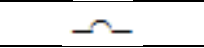 \\
\hline & Sulco & & мимимимим \\
\hline & Ravina & Tricart (1965) & $\cdots$ \\
\hline & Voçoroca & $\begin{array}{l}\text { Tricart (1965); } \\
\text { Verstappen e Zuidam (1975) }\end{array}$ & 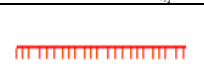 \\
\hline & Colo topográfico & Tricart (1965) & の \\
\hline & Morro Testemunho & $\begin{array}{l}\text { Tricart (1965); } \\
\text { Verstappen e Zuidam (1975) }\end{array}$ & 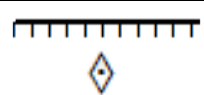 \\
\hline & Colúvio & \multirow{3}{*}{ Tricart (1965) } & \\
\hline & Ruptura topográfica suave & & 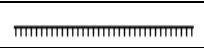 \\
\hline & Ruptura topográfica abrupta & & 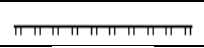 \\
\hline \multirow{7}{*}{$\begin{array}{c}\text { AÇÃO DAS } \\
\text { ÁGUAS } \\
\text { CORRENTES }\end{array}$} & Cascata & Tricart (1965) & $\rightarrow \bar{\square}$ \\
\hline & Vale em $V$ & \multirow{2}{*}{$\begin{array}{l}\text { Tricart (1965); } \\
\text { Verstappen e Zuidam (1975) }\end{array}$} & $>>>>$ \\
\hline & Vale em fundo plano & & $1 \quad 1 \quad 1 \quad 3$ \\
\hline & Drenagem pluvial & \multirow{2}{*}{ Tricart (1965) } & 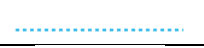 \\
\hline & Lagos & & \\
\hline & Leque aluvial & Verstappen e Zuidam (1975) & $\mathbb{A}$ \\
\hline & $\begin{array}{l}\text { Acumulação de Planície e Terraço Fluvial } \\
\text { (Aptf) }\end{array}$ & Tricart (1965) & \\
\hline \multirow{5}{*}{$\begin{array}{l}\text { MODELADO } \\
\text { ANTRÓPICO }\end{array}$} & Superficie construída & \multirow{3}{*}{$\begin{array}{l}\text { Tricart (1965) } \\
\text { Verstappen e Zuidam (1975) }\end{array}$} & \\
\hline & Mineração & & x \\
\hline & Terraço agrícola & & $\pi$ \\
\hline & Barragem & Versptappen e Zuidam (1975) & $><$ \\
\hline & Ruptura antrópica & Tricart (1965) & 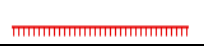 \\
\hline \multirow{4}{*}{ MORFOMETRIA } & Linha de cumeada abrupta & Verstappen e Zuidam (1975) & $x-x-x-x-x-x-x-x-x-x-x-x-x-x$ \\
\hline & Linha de cumeada suave & Tricart (1965) & (2............... \\
\hline & Curva de nível & \multirow{2}{*}{$\begin{array}{l}\text { Tricart (1965) } \\
\text { Verstappen e Zuidam (1975) }\end{array}$} & $\longrightarrow$ \\
\hline & Pontos cotados & & $x$ \\
\hline $\begin{array}{c}\text { CONVENÇÕES } \\
\text { CARTOGRÂFICAS }\end{array}$ & Limite da Bacia & - & \\
\hline
\end{tabular}

A Carta Clinográfica foi organizada de acordo com os procedimentos propostos por De Biasi (1992), adaptados ao ambiente digital do software ArcGIS®.
As classes foram determinadas em porcentagem a partir de limites consagrados, estabelecidos pela legislação nacional e por pesquisas internacionais. $\mathrm{O}$ Quadro 2 mostra as 
seis classes, com suas respectivas cores e a base

para determinação de seus limites.

Quadro 2. Classes de declividade para a Alta Bacia do Rio Passa Cinco. Fonte: Adaptado de De Biasi (1992).

\begin{tabular}{|c|l|l|}
\hline $\begin{array}{c}\text { Classes de } \\
\text { Declividade }\end{array}$ & Cor & \multicolumn{1}{c|}{ Limite } \\
\hline$<2 \%$ & & Áreas com alta possibilidade de alagamentos ou enchentes \\
\hline $2-5 \%$ & & $5 \%$ é o limite urbano-industrial determinado em pesquisas internacionais \\
\hline $5-12 \%$ & $\begin{array}{l}12 \% \text { constitui-se no limite mais comum de declive para o emprego de } \\
\text { mecanização da agricultura no Brasil }\end{array}$ \\
\hline $12-30 \%$ & $\begin{array}{l}30 \% \text { é o limite estabelecido para o parcelamento livre do solo para fins urbanos, } \\
\text { conforme a Lei Federal } \mathrm{n}^{\circ} 6.766 / 79-\text { Lei Lehmann }\end{array}$ \\
\hline $30-47 \%$ & $\begin{array}{l}\text { De acordo com a Lei Federal } \mathrm{n}^{\circ} 12.651 / 2012, \text { que estabelece o Código Florestal, } \\
47 \% \text { é o limite máximo para o corte raso da vegetação }\end{array}$ \\
\hline$<47 \%$ & $\begin{array}{l}\text { Acima de 47\% são consideradas áreas de uso restrito, conforme o Art. 11 do } \\
\left.\text { Código Florestal (Lei Federal } \mathrm{n}^{\circ} 12.651 / 2012\right)\end{array}$ \\
\hline
\end{tabular}

A Carta de Densidade de Drenagem ou de Densidade de Dissecação do Relevo foi elaborada segundo a proposta de Hubp (1988). De acordo com o autor, a Densidade de Dissecação permite, além da análise das drenagens, a interpretação dos resultados das ações destes cursos d'água na geração de talvegues. Neste produto cartográfico, foi identificada a extensão dos talvegues por unidade de área $\left(\mathrm{m} / \mathrm{m}^{2}\right)$.

Para a adaptação da proposta de Hubp (1988) para o meio digital, a área estudada foi dividida em quadrículas de $500 \mathrm{~m}$ de lado e $250.000 \mathrm{~m}^{2}$ de área. Em seguida, somou-se o comprimento total de talvegues no interior de cada quadrícula e dividiu-se pela área $\left(250.000 \mathrm{~m}^{2}\right)$. $\mathrm{O}$ valor resultante foi a Densidade de Drenagem (Dd). Os valores de Dd foram inseridos no centro das quadrículas e interpolados para a geração de um TIN (Triangular Irregular Network) posteriormente convertido em Raster. Uma paleta de cores foi selecionada para a representação da Densidade de Drenagem, sendo a cor verde relacionada com o menor valor e a cor vermelha referente ao maior valor de $\mathrm{Dd}$.

A Carta de Profundidade de Drenagem ou de Profundidade de Dissecação, conforme Hubp (1988), destaca a altura vertical entre a linha de cumeada e o talvegue, determinando as maiores profundidades de erosão linear e a distância transversal dos talvegues.

Utilizando-se novamente do sistema de quadrículas com $500 \mathrm{~m}$ de lado, a diferença entre a altitude máxima e a altitude mínima foi mensurada no interior de cada quadrícula, a partir das cotas das curvas de nível. O valor final de desnível altimétrico foi atribuído ao ponto central das quadrículas. Os valores foram interpolados para a geração de um TIN, que em seguida foi convertido para Raster. A graduação de cores selecionada indica que nos locais onde predomina a tonalidade verde ocorrem os menores desníveis altimétricos $(0$ - zero), enquanto a coloração vermelha indica a maior variação altimétrica $(259,6 \mathrm{~m})$.

A Carta de Lineamentos foi elaborada a partir da interpretação da Base Cartográfica. De acordo com Hubp (1988), os lineamentos são o reflexo de atividades endógenas, que se apresentam de forma retilínea ou ligeiramente curvada. A cartografia de lineamentos permite a quantificação do comprimento total dos lineamentos, a definição de zonas com maior ou menor intensidade de fraturas, setores afetados por esforços maiores ou menores, por exemplo.

Os lineamentos da Alta Bacia do Rio Passa Cinco foram divididos em três classes, de acordo com o mapeamento elaborado por Andrade (2018):

- $\quad$ Lineamentos de $1^{\mathrm{a}}$ ordem: correspondem às retilinidades identificadas em canais de $1^{\mathrm{a}}$ ordem;

- $\quad$ Lineamentos de $2^{\mathrm{a}}$ ordem ou de ordens superiores: traçados sobre canais de $2^{\mathrm{a}}$ ordem ou de ordens superiores;

- $\quad$ Lineamentos identificados por Facincani (2000): compilados do Mapa Morfotectônico produzido pela autora.

Os lineamentos de $1^{\mathrm{a}}$ e $2^{\mathrm{a}}$ ordens e ordens superiores foram vetorizados em formato de linha no $\operatorname{ArcMap}^{\mathrm{TM}}$, quando as drenagens apresentaram extensão linear aceitável para sugerir influências estruturais naturais sobre a organização da rede de canais ou quando foi constatada a existência de cotovelos de drenagem, nos quais as curvas se aproximam de ângulos com $90^{\circ}$.

Em seguida, através do software Spring ${ }^{\circledR}$, foram produzidas quatro rosetas com as direções predominantes dos lineamentos, sendo uma para os de $1^{\mathrm{a}}$ ordem, uma para os de $2^{\mathrm{a}}$ ordem ou superiores, uma para os lineamentos de Facincani (2000) e, por último, uma roseta para o conjunto total. 


\section{Resultados e discussão}

A Alta Bacia do Rio Passa Cinco está situada em uma área transicional entre os macrocompartimentos geomorfológicos das Cuestas Basálticas e da Depressão Periférica Paulista, o que confere à área de estudo características altimétricas contrastantes.

As Cartas Clinográfica e de Profundidade de Drenagem mostram o destaque topográfico do Front Cuestiforme e dos Morros Testemunhos. A Carta de Densidade de Drenagem mostra que o trabalho erosivo fluvial está concentrado ao longo do Rio Passa Cinco e de seus afluentes principais: na margem esquerda, o Rio Pirapitinga e Córrego Monjolo Grande, e na margem direita, o Ribeirão da Cachoeira, o Rio da Cachoeira e o Córrego Cantagalo. A Carta de Lineamentos exibe a influência estrutural evidente nas principais drenagens e córregos. Destaca-se o Rio Passa Cinco, com orientação de seu traçado em direção a NW-SE (Figura 2).

Os diagramas de rosetas (Figura 3) apontam lineamentos direcionados preferencialmente em sentido E-W e secundariamente para NW-SE e NE-SW, em concordância com dados apresentados por Facincani (2000) para a região de São Carlos, Piracicaba e Rio Claro.

A interpretação das cartas produzidas, a análise das bibliografias consultadas e a realização de trabalhos de campo permitiram identificar que há dinâmicas diferenciadas na área a qual pode ser melhor compreendida a partir de 3 setores geomorfológicos - Reverso da cuesta, Front cuestiforme e Depressão Periférica Paulista (Figura 2A e 2B) - que possibilitam uma análise pormenorizada do relevo da bacia.

O Reverso é dominado pela Formação Itaqueri, de origem fluvio-continental e constituída por materiais arenosos, folhelhos e conglomerados (Perrota et al., 2005). O tipo de solo predominante é o Latossolo Vermelho Amarelo que, conforme Santos e Ladeira (2006), apresenta aspecto argiloso com perfis lateríticos adjacentes. As nascentes estão dominantemente situadas em declives de 5$12 \%$ e $12-30 \%$ (Figura 2B).

Rupturas topográficas abruptas e suaves marcam a transição dos topos das colinas, em geral com declives baixos de $<2 \%$ e $2-5 \%$, para as vertentes de inclinação mais acentuadas (5-12\% e 12-30\%) (Figura 2B). Estas mudanças de declividade coincidem, em diversos pontos, com alterações internas das características dos Latossolos Vermelho Amarelos, que são diferenciados pela ocorrência das Unidades Três Barras e Itororó.

A Profundidade de Drenagem apresenta, em geral, baixos valores, dados pelas tonalidades verdes (Figura 2A). No entanto, nas nascentes do Rio da Cachoeira, do Ribeirão da Cachoeira e do Córrego Cantagalo, é possível observar valores intermediários (cores amarelas, Figura 2A), que concordam com áreas de declividades mais acentuadas (5-12\% e 12-30\%) (Figura 2B).

Os dados apresentados na Carta de Densidade de Drenagem (Figura 2C) mostram valores elevados ao longo do Ribeirão da Cachoeira, do Rio da Cachoeira e dos Córregos do Cantagalo e da Lapa. Andrade (2018) afirma que tal fato está relacionado aos trajetos realizados por estes afluentes obsequentes do Rio Passa Cinco, que transicionam para a Depressão Periférica passando pelo Front Cuestiforme. O degrau topográfico, originado pela resistência litológica basáltica das Cuestas, proporciona acúmulo de energia, que dinamiza a ação erosiva do sistema fluvial. 


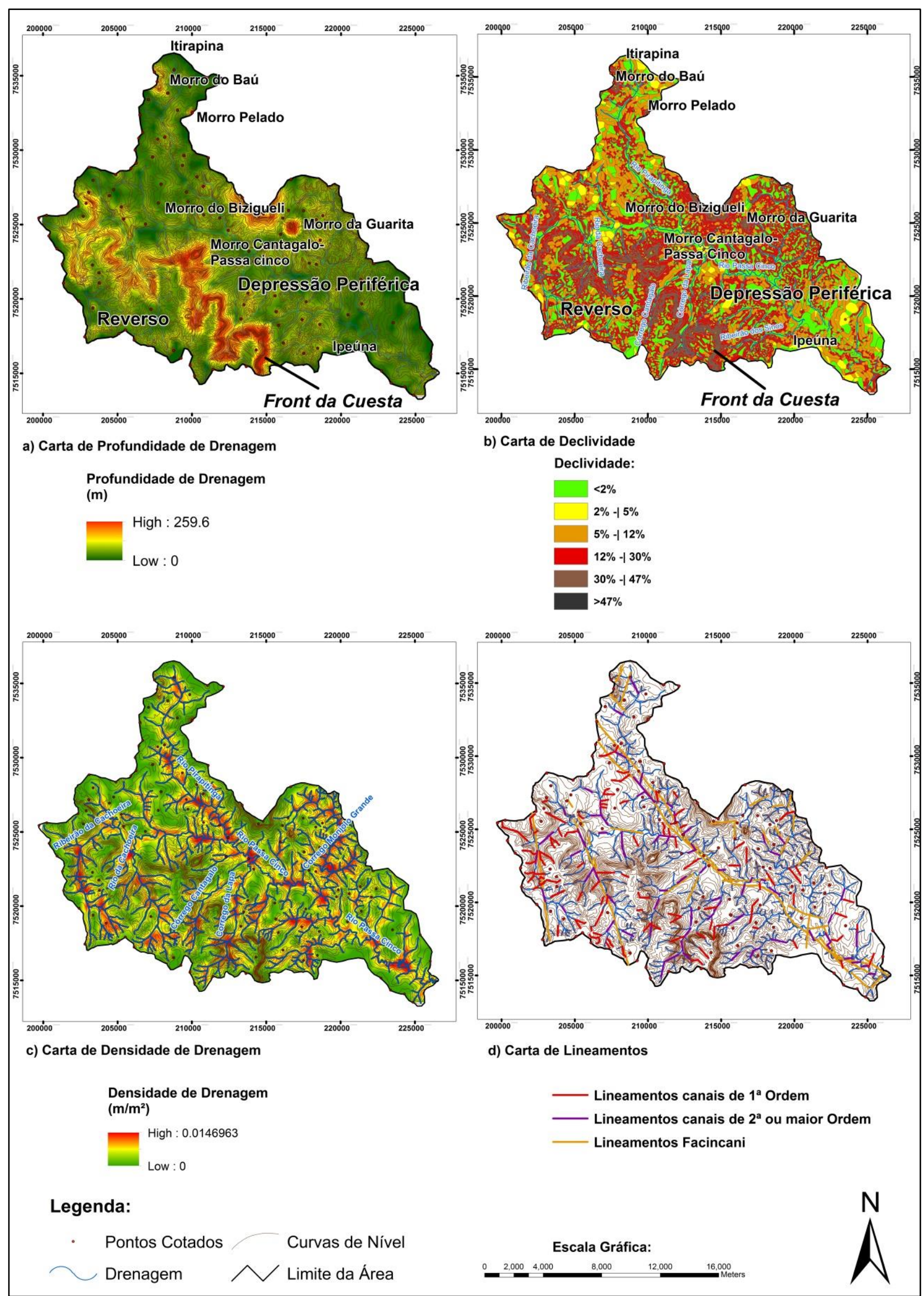

Figura 2. Cartas Morfométricas da Alta Bacia do Rio Passa Cinco (SP). 


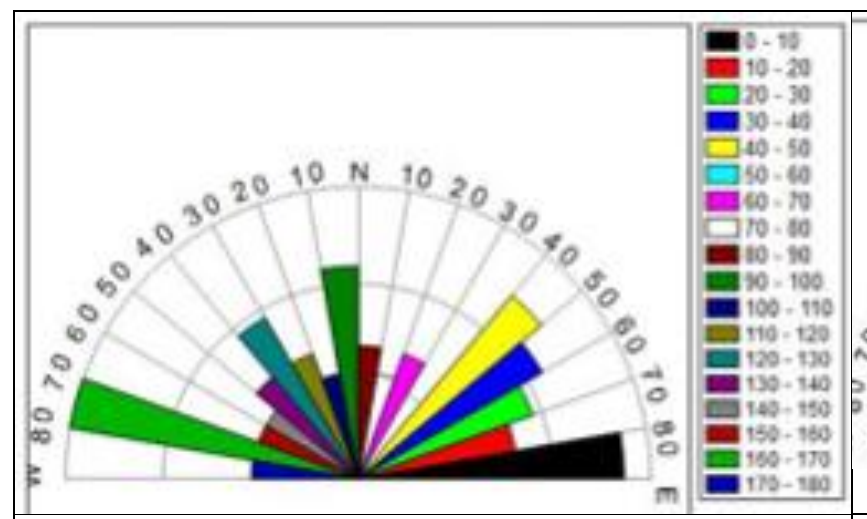

A) Direções de lineamentos sobre canais de $1^{\mathrm{a}}$ ordem

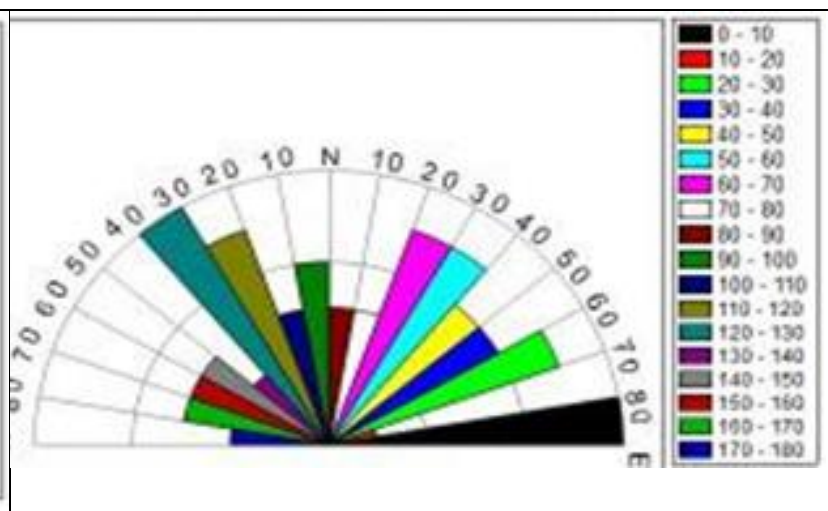

B) Direções de lineamentos sobre canais de $2^{\mathrm{a}}$ ou ordens superiores.

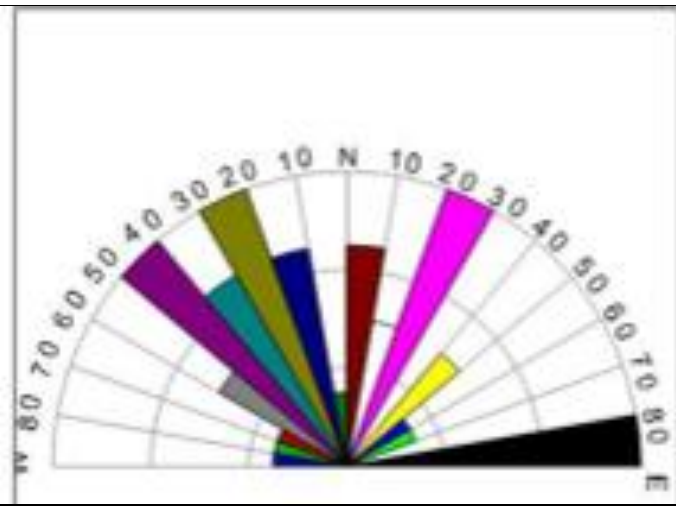

C) Direções dos

lineamentos de Facincani (2000).

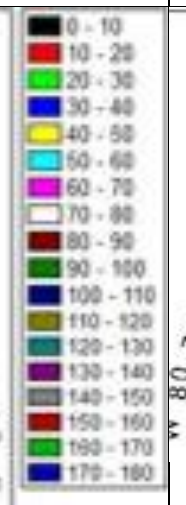

D) Direções gerais dos lineamentos cartografados para a Alta Bacia do Rio Passa Cinco -SP.

Figura 3. Rosetas com as direções de lineamentos identificados para a Alta Bacia do Rio Passa Cinco (SP).

No Ribeirão da Cachoeira e no Rio da Cachoeira, nos quais ocorrem os valores máximos de Densidade de Drenagem $\left(0,014,69 \mathrm{~m} / \mathrm{m}^{2}\right)$ (Figura 2C), constata-se o controle morfoestrutural através de dois lineamentos cartografados por Facincani (2000) (Figura 2D). O lineamento NWSE realiza o direcionamento do Rio da Cachoeira, desde suas nascentes até o sopé do Front da Cuesta(Figura 2D).

O lineamento $\mathrm{N}-\mathrm{S}$ influencia o alto e o médio curso do Ribeirão da Cachoeira (Figura 2D), que, ao atingir a Depressão Periférica Paulista, tem sua direção alterada para NE-SW por um lineamento de $2^{\mathrm{a}}$ ordem. O baixo curso do Ribeirão da Cachoeira é influenciado pelo grande lineamento NW-SE do Rio da Cachoeira, tendo novamente sua direção modificada.

Já os elevados valores de Profundidade de Dissecação e de Densidade de Drenagem (Figura 2A e 2C) observados para o Córrego da Lapa, que recebe as citadas drenagens, podem estar relacionados com o controle estrutural exercido por um falhamento de direção NW a WNW identificado por Santos e Ladeira (2006), que proporcionou localmente a acomodação lado a lado dos estratos Botucatu e Serra Geral.

Verifica-se, ainda, que cursos d'água secundários situados no Reverso apresentam influência morfoestrutural marcada por lineamentos de $1^{\mathrm{a}}$ e $2^{\mathrm{a}}$ ordens (ou de ordens superiores), com predomínio de direções NW-SE e E-W (Figura 2D). Para Santos e Ladeira (2006), estes lineamentos são responsáveis por forte influência sobre a rede de drenagem atual, que ao transicionar para os setores do Front de Cuesta resultam em escarpas festonadas e, em escala de maior detalhe, em vales suspensos e escarpas facetadas.

Nas cabeceiras das drenagens, controladas por lineamentos de $1^{\mathrm{a}}$ ordem, observam-se indícios de prováveis capturas de drenagem originadas pelo processo de erosão regressiva e consequente arrasamento das linhas de cumeadas. Estas possíveis capturas destacam-se no limite SW da área de estudo, nos divisores de águas das subbacias do Ribeirão da Cachoeira, do Rio da Cachoeira e do Córrego Cantagalo (Figura 4). 


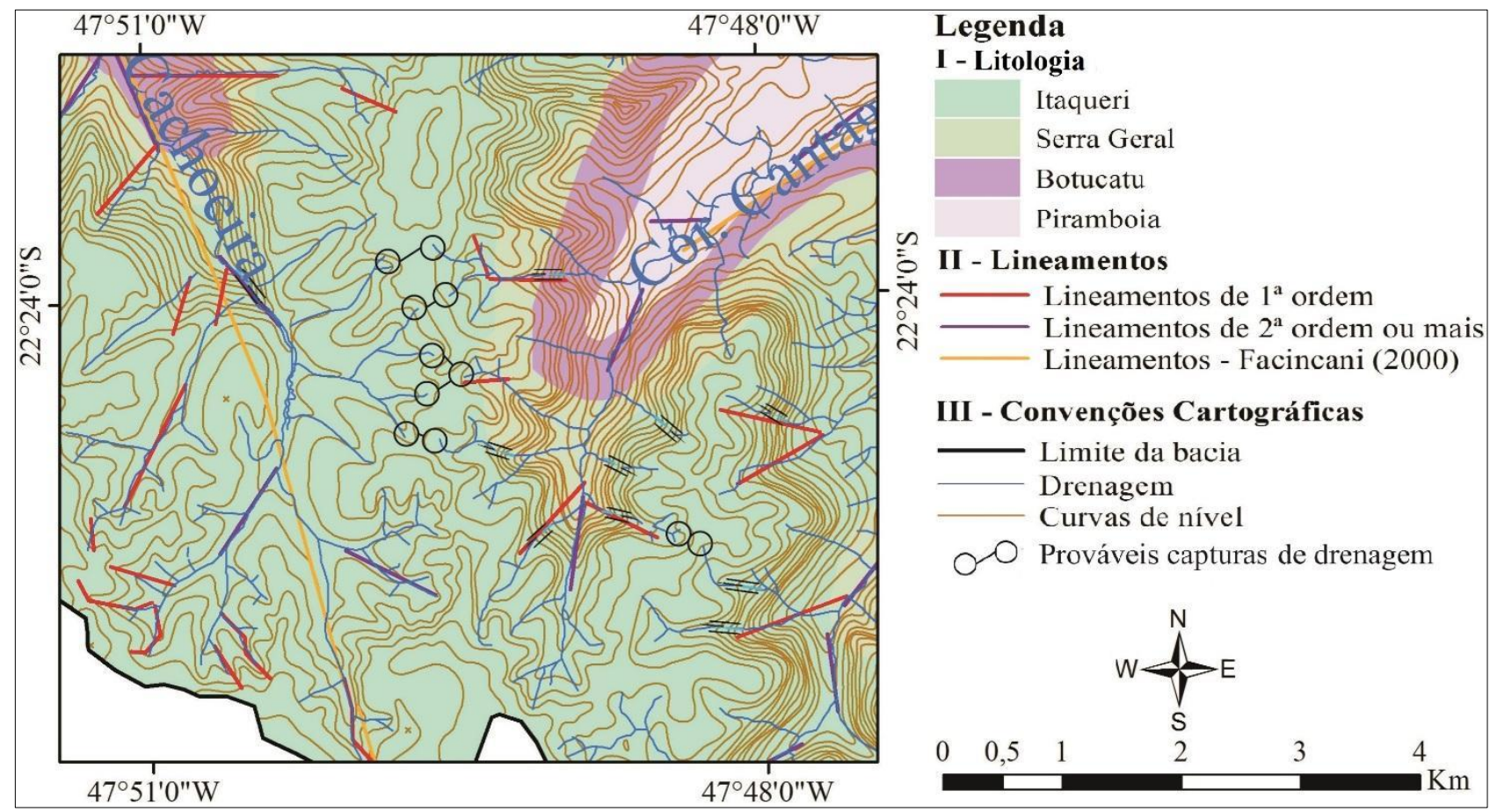

Figura 4. Prováveis capturas de drenagem no trecho SW da Alta Bacia do Rio Passa Cinco, no divisor de águas entre as sub-bacias do Rio da Cachoeira e do Córrego Cantagalo.

Essas evidências da dinâmica erosiva das drenagens vinculam-se também ao fato do perfil longitudinal dessas ser influenciado diretamente pelo Front Cuestiforme, que é a feição geomorfológica mais expressiva da área de estudo. As litologias que sustentam este compartimento do relevo são compostas pela interdigitação de basaltos da Formação Serra Geral e arenitos da Formação Botucatu (Figura 5).

A escarpa do Front da Cuesta, destacada pelo desnível altimétrico, é caracterizada por cornija retilínea e abrupta e tálus com presença de rampas coluviais (Figura 5), além de declives acentuados, entre $30-47 \%$ e acima de $47 \%$ (Figura 2B), que definem a transição para o compartimento da Depressão Periférica Paulista, no qual ocorrem declives predominantes de 12-30\%.

O desnivelamento topográfico provocado pela presença do Front Cuestiforme, o qual é observado no recorte da Carta Geomorfológica
(Figura 5), na Carta de Declividade (Figura 2B) e na Carta de Profundidade de Dissecação (Figura 2A), gera quedas d'água nos afluentes do Rio Passa Cinco.

Uma sutil diferenciação entre as declividades ocorrentes nos setores SE e NW do Front Cuestiforme pode ser constatada na Figura 2B. No segmento SE, as declividades alcançam as maiores porcentagens ( $30-47 \%$ e $>47 \%$ ), enquanto na parte NW, a classe predominante é de 12-30\%.

Esta diferenciação do Front da Cuesta é mais evidente na Carta de Profundidade de Dissecação (Figura 2A), na qual se verifica que o trecho SE é destacado por tonalidades avermelhadas, com o degrau topográfico atingindo seu maior desnível de $259,6 \mathrm{~m}$. A parte NW, por sua vez, apresenta valores intermediários de Profundidade de Dissecação, predominando tonalidades de amarelo e laranja. 


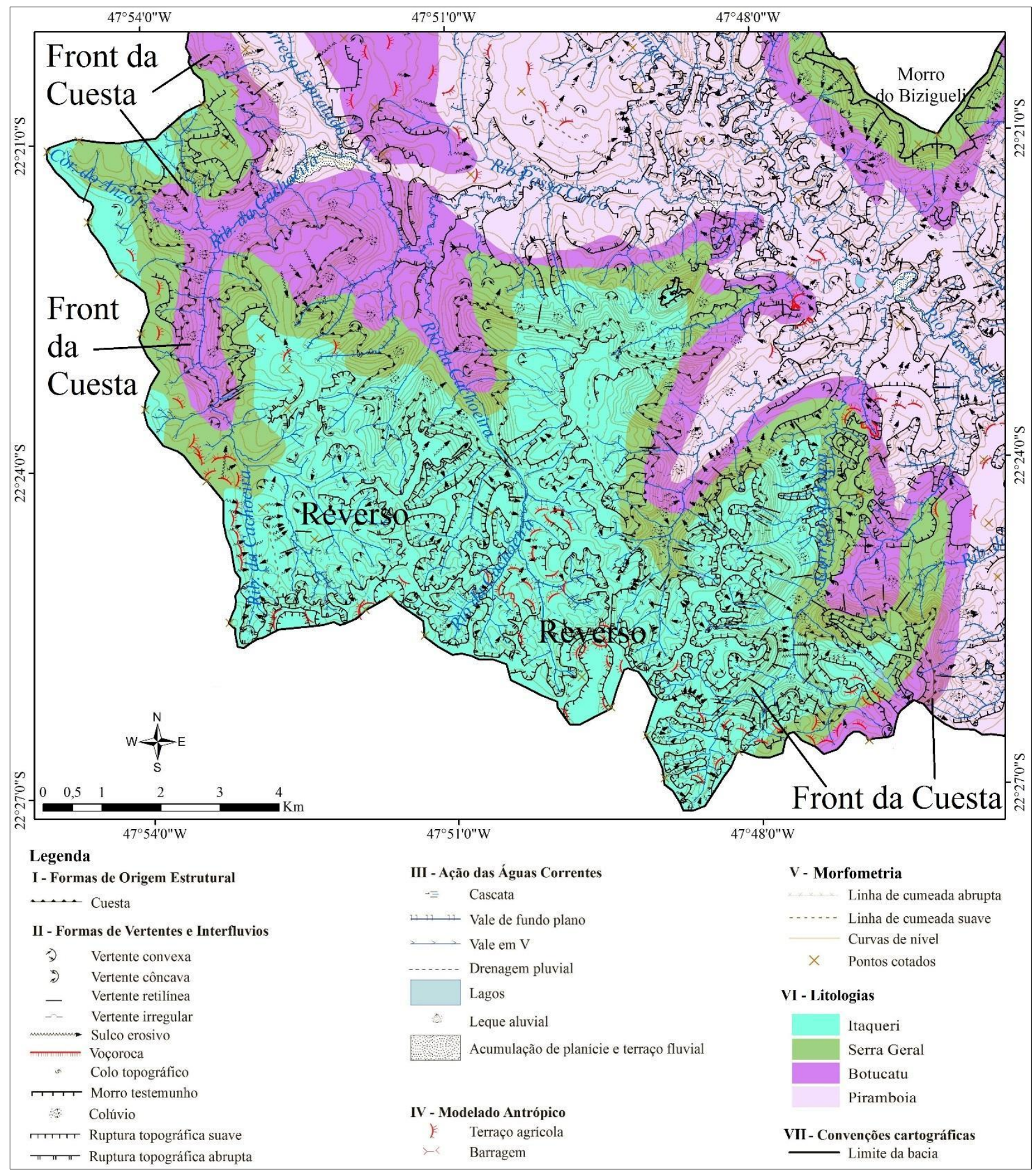

Figura 5. Recorte da Carta Geomorfológica destacando o Reverso e o Front da Cuesta.

A Formação Botucatu, no setor SE, ocupa uma menor extensão (Figura 5), fato que pode evidenciar que os arenitos foram erodidos por ação da drenagem, promovendo a geração de um degrau topográfico mais pronunciado na zona do Front, enquanto no setor NW, a existência de um desnível altimétrico menos significativo estaria ligado ao maior alargamento do estrato Botucatu, com materiais arenosos ainda não retrabalhados pela ação fluvial como no trecho SE.
A subdivisão das Cuestas em dois segmentos (SE e NW) apresenta também coincidência com o lineamento NW-SE, mapeado por Facincani (2000), que condiciona o Rio da Cachoeira (Figura 2D). A existência de uma falha normal associada a este lineamento pode ter sido responsável pelo soerguimento da porção SE do Front Cuestiforme e de seu Reverso em relação ao setor NW, que se reflete nas variações dos valores interpolados da Carta de Profundidade de Drenagem (Figura 2B). 
No trecho SE da Frente de Cuesta predominam lineamentos de $2^{\mathrm{a}}$ ordem e de ordens superiores com direção NE-SW, enquanto no fragmento NW, dominam os grandes lineamentos em sentido NW-SE (Facincani, 2000), e lineamentos secundários de $1^{\mathrm{a}}$ e $2^{\mathrm{a}}$ ordens ou ordens superiores em orientação NE-SW e NW-SE (Figura 2D).

O Front Cuestiforme é caracterizado por pontos de reentrâncias, que estão associados a altos valores de Densidade de Dissecação das drenagens obsequentes (Rio da Cachoeira, Ribeirão da Cachoeira, Córrego Cantagalo e Córrego da Lapa) que nascem no Reverso e se direcionam para a Depressão Periférica Paulista (Figura 2C).

Os altos valores da Densidade de Drenagem indicam intensa erosão fluvial promovida pelo entalhamento dos talvegues que se acomodaram sobre falhamentos e fraturamentos dos terrenos. As ações erosivas sobre estes pontos de maior suscetibilidade ao ataque fluvial resultaram em um recuo das escarpas cuestiformes, bem como a regressão do Front.

Penteado (1976) destacou a ocorrência de setores retilíneos nas drenagens das Cuestas, que podem ser observados nos recuos paralelos das escarpas nos trechos banhados pelo Córrego Cantagalo, pelo Ribeirão da Cachoeira e pelo Rio da Cachoeira. Segundo a autora, estas retilinizações são um reflexo da influência estrutural, com ênfase para os processos tectônicos.

Facetas trapezoidais e triangulares foram constatadas in loco. De acordo com Facincani(2000), estas feições estão associadas ao controle tectônico do relevo realizado por basculamentos, falhamentos e, ainda, pela erosão fluvial.

Por último, na Figura 6, observa-se um ponto do setor de Front cuestiforme que provavelmente se romperá no futuro, gerando um morro testemunho. Além da alta declividade, que atinge valores acima de 47\%, observa-se uma alta Profundidade de Dissecação. Um colo topográfico no setor do futuro cut-off pode ser notado entre duas curvas de nível a $920 \mathrm{~m}$ de altitude, no trecho mais estreito da cornija, na qual a distância entre os dois lados apresenta cerca de 45,5 m.

Ao norte desta estreita cornija, observa-se um morro testemunho nomeado como "Interfluvio Cantagalo-Passa Cinco", devido ao posicionamento geográfico com relação a estas duas drenagens.

O Morro do Interflúvio Cantagalo-Passa Cinco é caracterizado por cornija bem demarcada com vertentes de declives entre $30-47 \%$ e $>47 \%$ (Figura 2B), topo aplainado e rampas de colúvios no entorno com declives predominantes de $12-30 \%$ (Figura 2B). A Profundidade de Dissecação apresenta valores médios e elevados, representados pelas cores amarelas e tons alaranjados (Figura 2A; Figura 6), enquanto a Densidade de Drenagem apresenta valores baixos (Figura 2C).

Outros quatros morros testemunhos são distinguidos na Alta Bacia do Rio Passa Cinco: Baú e Pelado, no setor N, e Bizigueli e Guarita, mais ao $S$ destes (Figura 7 ).

De acordo com Penteado (1976), estes morros testemunhos apresentam uma inclinação média entre $5^{\circ}$ e $6^{\circ}$ em sentido NW, que é maior que aquela encontrada no Reverso. Tais inclinações, que são bem observadas em trabalho de campo através da linha dos topos dos morros, indicam evidências de falhamentos ocorridos no final do Terciário (atuais períodos Paleógeno e Neógeno) e no início do Quaternário (Penteado, 1976), aos quais se seguiram o entalhamento de vales, o seccionamento e a desconexão dos morros do restante das Cuestas.

O Morro do Baú está situado na transição entre as litologias das Formações Piramboia e Serra Geral (Figura 7A), sobre as quais verifica-se a presença de Neossolos Litólicos e Quartzarênicos.

$\mathrm{O}$ topo apresenta formato aplainado e o entorno é caracterizado pela ocorrência de rampas coluviais (Figura 7A), nas quais predominam declives de 5-12\% e 12-30\% (Figura 7B). Terraços agrícolas foram cartografados sobre a Formação Piramboia. A Profundidade de Dissecação do Morro do Baú apresenta valores intermediários a altos, representados pelos tons de amarelo e laranja (Figura 7C), o que indica sua topografia evidenciada. A Densidade de Drenagem é predominantemente baixa no morro testemunho (Figura 7D).

A leste do Morro do Baú localiza-se o Rio Pirapitinga, no qual estão concentrados os maiores valores de Densidade de Drenagem do setor N da bacia. Cursos d'água com nascentes no morro testemunho, ao vencerem o desnível altimétrico, acumulam energia nas suas confluências com o Pirapitinga (Figura 7D).

O Morro do Baú está localizado entre quatro lineamentos cartografados por Facincani (2000) e dois outros lineamentos identificados nessa pesquisa (Figura 2D). $\mathrm{O}$ lineamento imediatamente a sul, de direção NW-SE, e outro a leste, de direção NE-SW, contribuem para a delimitação atual do morro testemunho e possivelmente determinam seu processo geomorfológico evolutivo. 


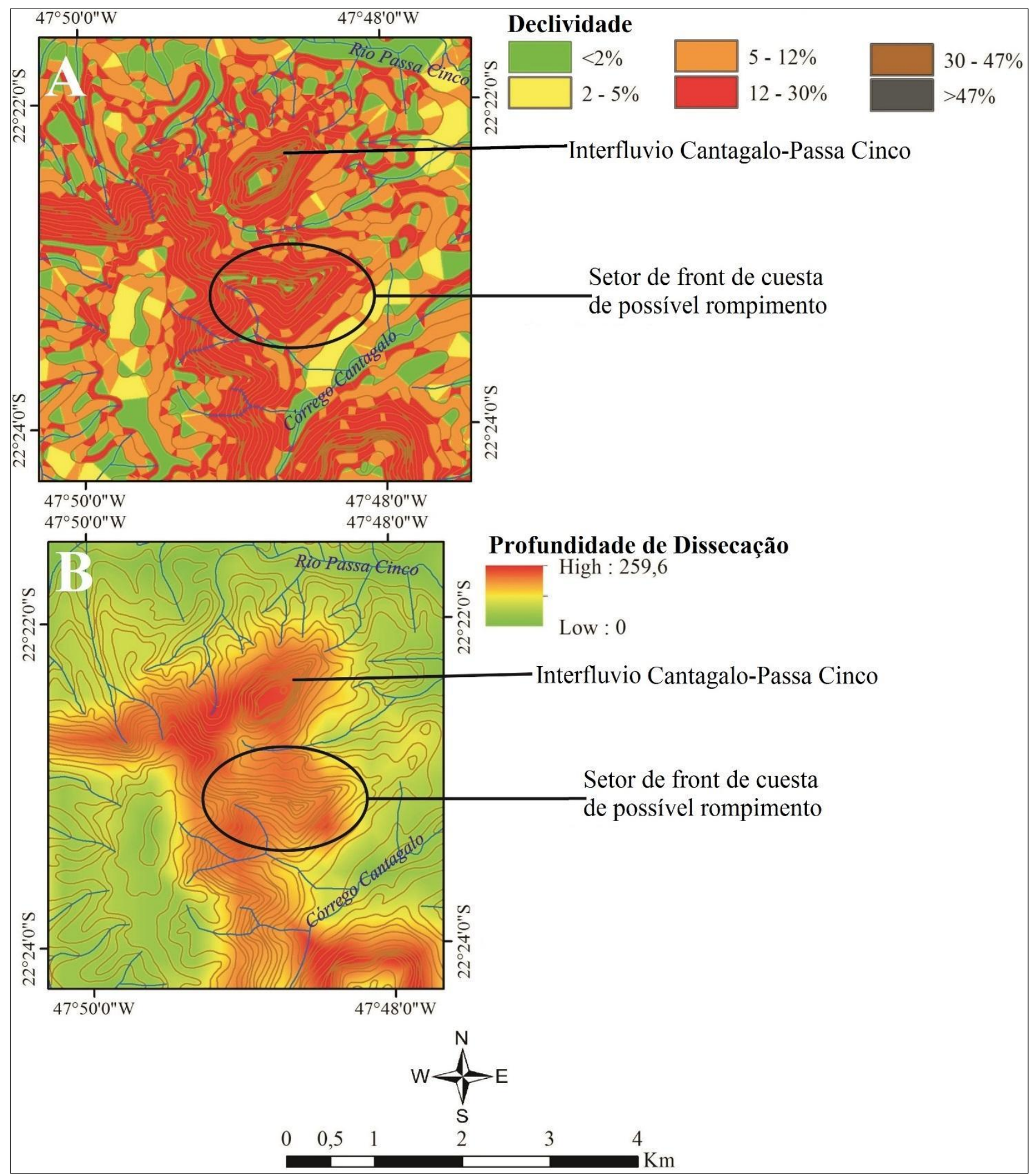

Figura 6. Front cuestiforme e Morro Testemunho Interflúvio Cantagalo-Passa Cinco. 
Revista Brasileira de Geografia Física v.13, n.02 (2020) 465-486.

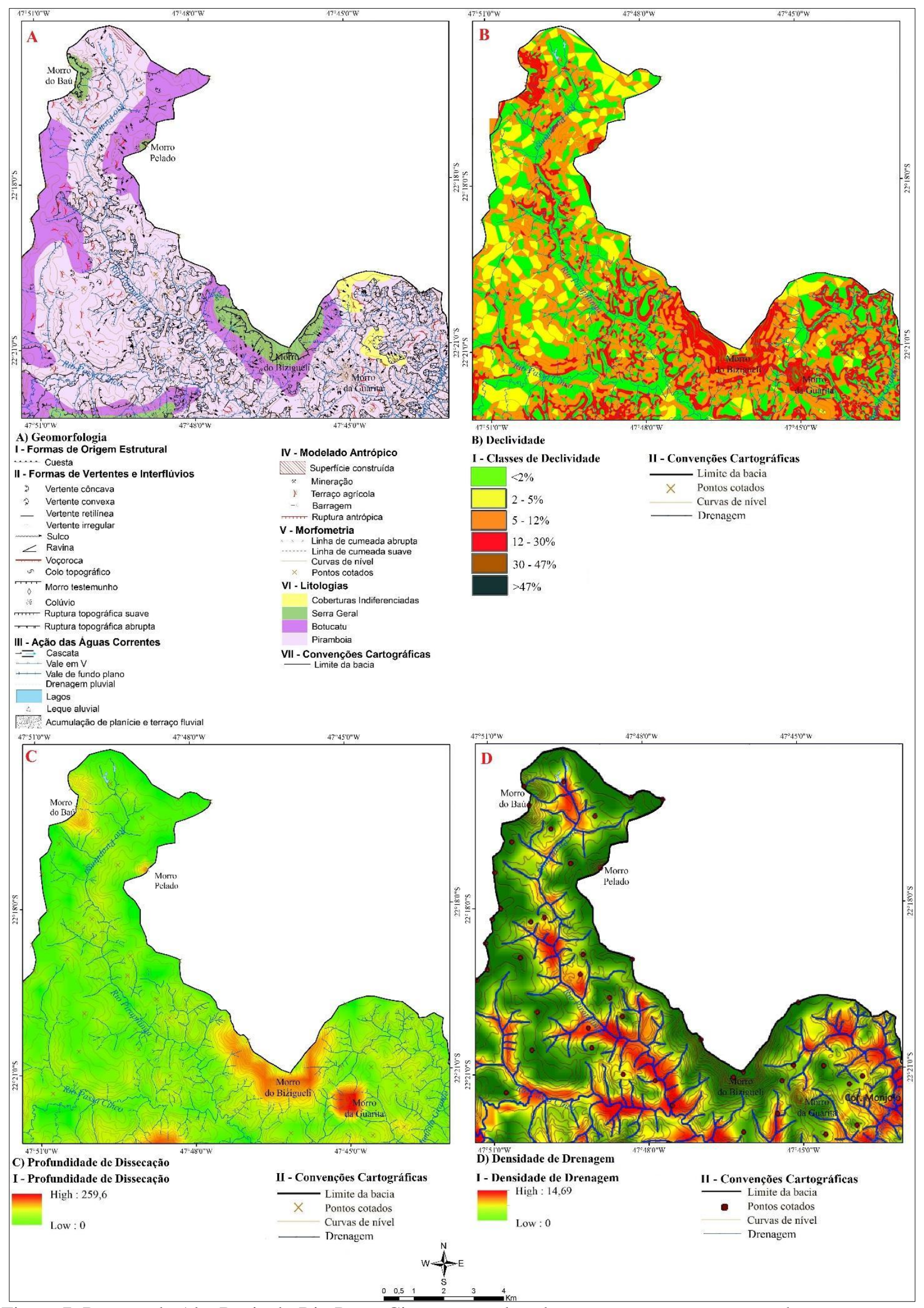

Figura 7. Recorte da Alta Bacia do Rio Passa Cinco, no qual se destacam os morros testemunhos. 
Ao norte do Morro do Baú, duas ravinas foram mapeadas sobre Neossolos Quartzarênicos derivados de arenitos da Formação Piramboia. A evolução destas feições pode estar ligada às características litológicas e pedológicas da área, já que, como afirma São Paulo (1989, citado por Filizola et al., 2011), os Neossolos Quartzarênicos são tipos de solos de maior suscetibilidade natural à instalação de processos erosivos lineares. Os lineamentos sobrepostos às ravinas não aparentam ter interferência direta em seus processos evolutivos, visto que estas não se apresentam no sentido dos alinhamentos

O Morro Pelado, por sua vez, está situado na margem esquerda do Rio Pirapitinga e apresenta como características topo aplainado e colúvios de entorno (Figura 7A) com declives predominantes de $12-30 \%$ e $30-47 \%$ (Figura 7B), que marcam a transição para áreas mais planas da Depressão Periférica Paulista.

Seu desenvolvimento ocorre sobre basaltos da Formação Serra Geral nas cotas altimétricas mais elevadas, enquanto sua base está situada sobre arenitos da Formação Botucatu (Figura 7A).

A Densidade de Drenagem (Figura 7D) apresenta valores baixos, devido à ausência de canais fluviais com nascentes no morro testemunho. A Profundidade de Drenagem (Figura 7C) evidencia o desnível altimétrico em relação ao entorno. Ao sul dos Morros do Baú e Pelado, observa-se que o Rio Pirapitinga é assinalado pela presença de leques aluviais (Figura 7A) situados em setores caracterizados por elevados valores de Densidade de Drenagem (Figura 7D), aliada à ocorrência dos arenitos da Formação Piramboia (Figura 7A), altamente suscetíveis aos processos erosivos.

Os pequenos afluentes perdem energia ao desaguar no Pirapitinga, resultando na acumulação de detritos nos setores de foz. As nascentes destes cursos d'água estão situadas em setores de declividades de 5-12\% e 12-30\% (Figura 7B).

$\mathrm{O}$ Rio Pirapitinga apresenta evidente controle morfoestrutural na direção NW-SE, desde o sul do Morro Pelado até seu deságue no Rio Passa Cinco. Este direcionamento também pode ser constatado na Carta Clinográfica, na qual o fundo de vale da drenagem fica evidenciado pelo tom verde (classe $<2 \%$ ) (Figura 2B).

Os morros testemunhos do Bizigueli e da Guarita estão localizados no trecho leste da área de estudo. A proximidade espacial indica que provavelmente, em algum período da história evolutiva, estes formavam um único conjunto, que atualmente está separado pela ação fluvial das nascentes do Córrego Monjolo Grande e de uma drenagem afluente do Rio Passa Cinco.

O Morro da Guarita está situado sobre arenitos da Formação Piramboia e é o único testemunho da Alta Bacia do Rio Passa Cinco com topo aguçado. Rampas coluviais estão situadas na transição para as áreas altimetricamente mais baixas (Figura 7A).

Dentre as características morfométricas, destacam-se as declividades, que variam entre 12$30 \%$ e $30-47 \%$ (Figura 7B). A Profundidade de Dissecação apresenta valores elevados, representados pelas cores amarelo, laranja e vermelho (Figura 7C). Os valores de Densidade de Drenagem variam de baixos a intermediários, conforme a Figura 7D. Os canais fluviais com nascentes no Morro da Guarita apresentam Densidades de Drenagem de valores médios e altos (Figura 7D).

$\mathrm{O}$ entorno do testemunho apresenta lineamentos mapeados por Facincani (2000), assim como lineamentos de $1^{\text {a }}$ ordem (Figura 2D). Em sua face $\mathrm{W}$, o lineamento de sentido N-S denota a influência morfoestrutural em seu desenvolvimento e na energia acumulada pelos canais fluviais (Figura 2D).

Em trabalho de campo, constatou-se que o trecho $\mathrm{W}$ do testemunho estrutura-se como uma face triangular, que de acordo com a Carta Clinográfica (Figura 7B), apresenta declives mais acentuados que no trecho E, além da ocorrência de vertentes retilíneas (Figura 7A), que podem estar relacionadas com a ocorrência do lineamento.

O Morro do Bizigueli está localizado em uma área transicional entre as Formações Serra Geral e Botucatu (Figura 7A). O topo plano caracteriza-se por declives de 2-5\% (Figura 7B). A cornija bem demarcada apresenta declividades de $30-47 \%$ (Figura 7B).

Nas áreas de rampas coluviais (Figura 7A), as vertentes são irregulares e caracterizadas pela presença de sulcos erosivos, que se desenvolvem em declives altos (12-30\% e 30-47\%) (Figura 7B).

Segundo Facincani (2000, p. 181), o Morro do Bizigueli é considerado um shutterridge, formado "[...] devido ao deslocamento imposto por feixe de falha direcional dextral de direção E-W".

Na Figura 8, observa-se que o Morro do Bizigueli apresenta maior elevação altimétrica na porção à direita da fotografia do que à esquerda. Esta variação tem influência direta da presença do lineamento E-W, ilustrado na Figura 2D. 


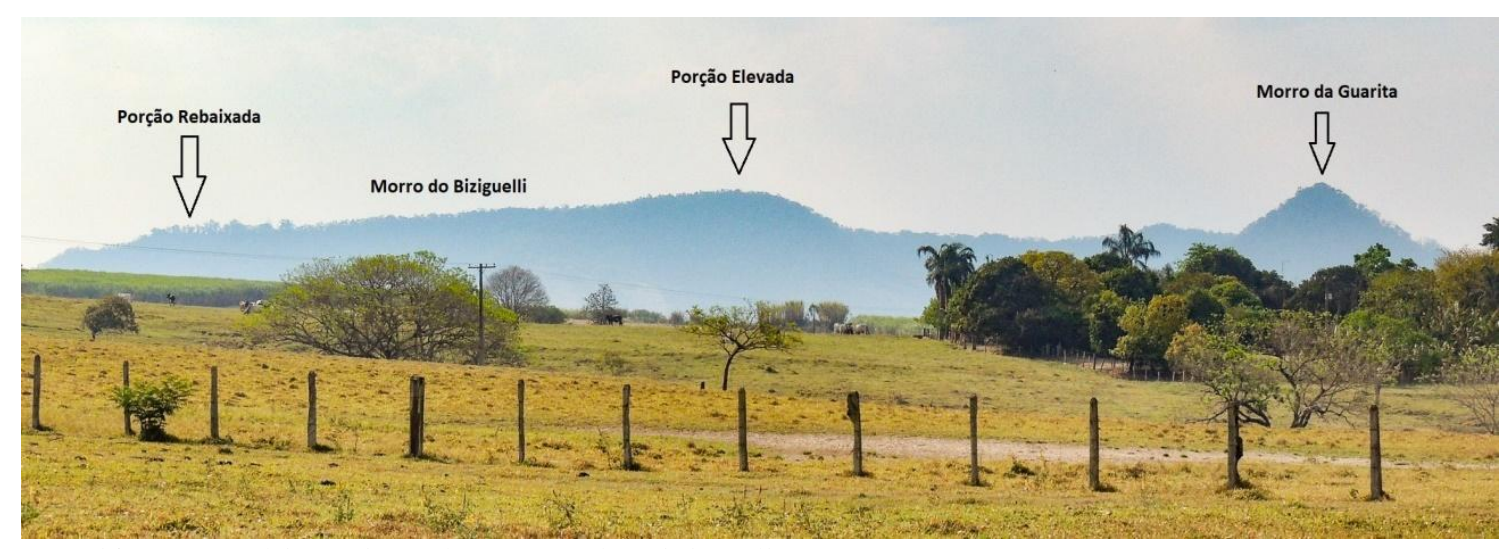

Figura 8. Diferenças altimétricas do Morro do Bizigueli.

A Profundidade de Drenagem apresenta altos valores (Figura 7C), indicando que $\mathrm{o}$ Bizigueli é uma saliência topográfica, enquanto a Densidade de Drenagem nas vertentes e no topo são baixas, sendo representada por tonalidades verdes.

Já os cursos d'água que nascem no Morro do Bizigueli, ao desaguarem no Rio Passa Cinco, apresentam elevados valores de Densidade de Drenagem (Figura 7C).

Na Figura 2D constata-se a ocorrência de lineamentos próximos ao Morro do Bizigueli. Aquele de direção aproximadamente E-W (Facincani, 2000) coincide com os setores de maiores declives e com o atual posicionamento da cornija do testemunho. Assim, pode-se destacar a influência do controle morfoestrutural no processo evolutivo na face $\mathrm{S}$ deste morro.

O Morro do Bizigueli está separado do Front das Cuestas pela principal drenagem da área de estudo - o Rio Passa Cinco - que tem seu curso estabelecido sobre grandes lineamentos de direção NW-SE identificados por Facincani (2000). Ressalta-se que a face SW do Bizigueli acompanha o direcionamento destes lineamentos principais, indicando evidências tectônicas no processo erosivo de suas vertentes e cornija SW.

Esses morros estão envolvidos por colinas suavizadas vinculadas à Depressão Periférica Paulista, com predomínio de baixas declividades, que variam de $<2 \%$ a $5-12 \%$, com colinas de topos amplos e aplainados (Figura 2B).

Conforme Penteado (1976), as vertentes convexizadas predominantes neste compartimento são reflexos da atuação morfoclimática da fase quente e úmida atual.

Nas concavidades frequentemente ocorrem nascentes de cursos d'água e formação de canais pluviais. A presença de sulcos erosivos está comumente associada às áreas alteradas por terraços agrícolas para plantio de cana-de-açúcar e aos campos utilizados como pastagens (Figura 9). 


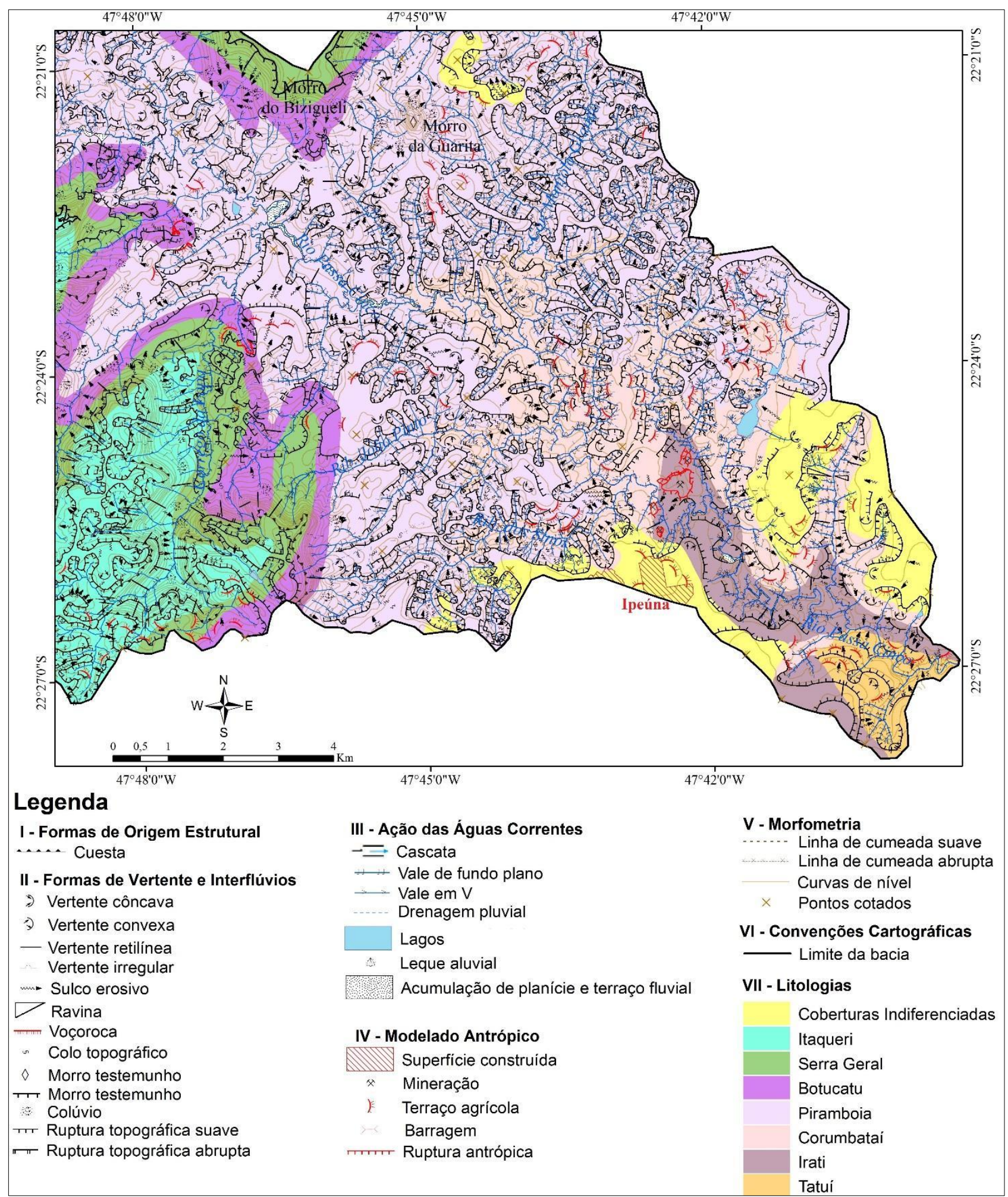

Figura 9. Recorte da Carta Geomorfológica no setor da Depressão Periférica. 
As rupturas topográficas abruptas e as rupturas topográficas suaves cartografadas (Figura 9) na Depressão Periférica marcam situações distintas, como: as diferenças abruptas de declividades ocorrentes, por exemplo, nas áreas marginais do Rio Passa Cinco que transicionam de declives entre $5-12 \%, 12-30 \%$ e $30-47 \%$ para $<2 \%$ e 2-5\% (Figura 2B); a distinção de limites entre diferentes litologias (Figura 9); e alterações de tipos de solos e variações internas de um mesmo tipo de solo.

As modificações abruptas de classes de declividade são caracterizadas por Facincani (2000) como escarpamentos secundários que revelam o controle tectônico do relevo. A autora afirma que estas feições são originadas de basculamentos de blocos e falhas, sendo consideradas como o resultado mais evidente da atuação da neotectônica regional. Tais escarpamentos secundários foram observados em trabalhos de campo no Rio Passa Cinco, no Córrego da Lapa e no Córrego Cantagalo e coincidem com os grandes alinhamentos apresentados na Carta de Lineamentos (Figura 2D).

A respeito das colinas caracterizadas por estas rupturas de declive, constata-se que estas se situam nas cotas altimétricas de 580-600 m, coincidentes com o que foi detalhado por Penteado (1976, p. 19):

Essas colinas se desdobram em patamares como pisos de degraus que descem em direção aos vales principais. Os patamares se correspondem em altimetria e forma e estão ligados à história recente da escavação dos vales regionais, num lapso de tempo colocado à época da elaboração do topo dos divisores (superfície interplanática pós-escavação da depressão periférica) e a época atual. Tratam-se dos níveis erosivos quaternários.

A influência morfoestrutural é detectada por meio da presença de cotovelos de drenagem, que resultam em mudanças bruscas de direcionamento dos cursos d'água, com ângulos de aproximadamente $90^{\circ}$.

Outro fator verificado em trabalho de campo e que mostra o controle morfoestrutural na área de estudo é a presença de soleiras formadas por diques de diabásio, que retém os materiais sedimentares gerando acumulações de planície e terraço fluvial (Aptf) (Figura 9). Cascalheiras encontradas nas áreas de terraços fluviais do Rio Passa Cinco, indicam, conforme Penteado (1976), fases atuais ou pré-atuais de deposição por transporte fluvial e têm relação com outros fatores, como a natureza do solo, posição topográfica e vertentes.

Quanto maior a proximidade da confluência entre o Rio Passa Cinco com o Rio da Cabeça e maior a distância do Front Cuestiforme, maior é a predominância de classes de declives baixos (Figura 2B). Os vales de fundo plano do Rio Pirapitinga, do Rio Passa Cinco e do Córrego Monjolo Grande são dominantemente caracterizados pela classe de declividade de menor porcentagem $(<2 \%)$.

Estes cursos d'água concentram baixos valores de Profundidade de Dissecação (Figura 2A), porém apresentam altos valores de Densidade de Drenagem (Figura 2C), indicando uma forte influência da erosão fluvial nos terrenos altimetricamente mais baixos da Depressão Periférica Paulista.

Do conjunto de terrenos relacionados à Depressão Periférica, destaca-se o Córrego Monjolo Grande (Figura 10), o qual tem suas cabeceiras situadas nos Morros testemunhos da Guarita e do Bizigueli, estando fortemente condicionadas pelos lineamentos estruturais, com ênfase para aqueles mapeados por Facincani (2000). O Córrego Monjolo Grande segue uma direção geral preferencial NE-SW, porém cotovelos de drenagem ao longo do curso d'água indicam alterações de sentido em seu traçado. Observam-se ainda indícios de prováveis capturas de drenagem, sendo que muitas nascentes de diferentes sub-bacias estão situadas a cerca de 140 $m$ de distância. 


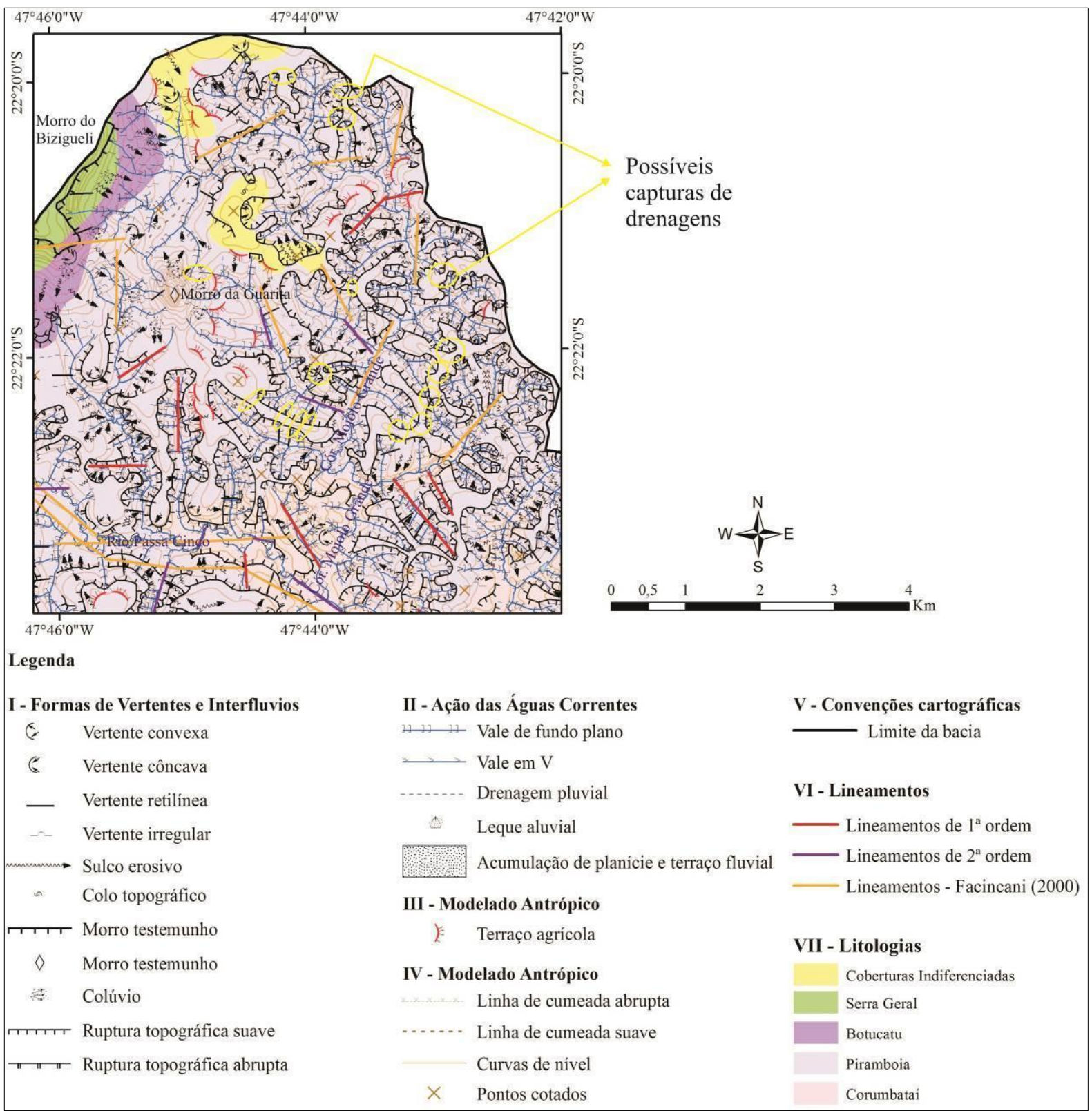

Figura 10. Possíveis capturas de drenagem na bacia do Córrego Monjolo Grande.

\section{Conclusões}

A Alta Bacia do Rio Passa Cinco está situada em uma área transicional entre a Depressão Periférica Paulista e as Cuestas Basálticas, apresentando uma elevada complexidade de formas, as quais provavelmente se devem à diferentes processos evolutivos.

Além da circundesnudação, considerado o fator clássico de origem e desenvolvimento destes dois macrocompartimentos do relevo, fatores tectônicos também necessitam serem avaliados para o entendimento das formas de relevo.

Os produtos cartográficos produzidos neste trabalho, quando analisados em conjunto, mostram um significativo controle das características morfoestruturais sobre os processos de evolução geomorfológica da área de estudo.
No Reverso estão situadas as nascentes de canais fluviais obsequentes, afluentes do Rio Passa Cinco - Córregos da Lapa e Cantagalo, Ribeirão da Cachoeira e Rio da Cachoeira - que cortam o Front Cuestiforme em direção a Depressão Periférica Paulista. Estas drenagens têm seus cursos comandados por grandes lineamentos, o que indica evidente controle estrutural sobre a ação fluvial no desenvolvimento do relevo. Estas drenagens acumulam energia ao passarem pelo Front da Cuesta, dinamizando sua ação fluvial.

O Front Cuestiforme, que constitui um degrau topográfico abrupto no qual os desníveis altimétricos podem atingir mais de $200 \mathrm{~m}$, apresenta diferentes morfologias nos setores SE e NW as quais se refletem nas variações de declividade e, sobretudo, pelas diferenciações de Profundidade de Dissecação. O lineamento sob o 
Rio da Cachoeira está situado neste seccionamento, o que indica uma forte influência estrutural sobre o Front da Cuesta.

$\mathrm{Na}$ Depressão Periférica Paulista, os Morros Testemunhos são altimetricamente contrastantes com as áreas de entorno. Segundo Penteado (1976) e Facincani (2000), estes morros estão ligados com as evidências de falhamentos ocorridos na área ao longo do Neógeno e do Paleógeno (antigo Terciário). Os lineamentos cartografados mostram indícios de que os morros testemunhos apresentam desenvolvimento geomorfológico associado com as características estruturais.

Dessa forma, constata-se que a interpretação de produtos cartográficos temáticos, aliada a pesquisas de campo e consultas bibliográficas permitiram aprofundar as reflexões sobre a complexidade geomorfológica das Cuestas e da Depressão Periférica no setor estudado. Entende-se que tais procedimentos técnicos e reflexões são passíveis de serem estendidos a outros setores do interior do Estado de São Paulo caracterizados por tais relevos, permitindo compreender a complexidade que envolve sua elaboração.

\section{Agradecimentos}

Ao Conselho Nacional de Desenvolvimento Científico e Tecnológico $(\mathrm{CNPq})$ pelo financiamento da pesquisa de Pós-Doutorado Junior (Processo $\mathrm{n}^{\circ}$ 155332/2016-3).

À Fundação de Amparo à Pesquisa do Estado de São Paulo (FAPESP), processo $\mathrm{n}$. 2016/25231-1.

\section{Referências}

Aguilar, R. L.; Cunha, C. M. L., 2015. Análise morfoestrutural de um setor da Serra da Atalaia, Analândia/Corumbataí (SP). Revista Brasileira de Geografia Física 8, 1410-1434.

Almeida, F. F. M., 1949. Relevo de "Cuestas" na Bacia Sedimentar do Paraná. Boletim Paulista de Geografia 3, 21-33.

Andrade, R. V., 2018. Morfometria da Alta Bacia do Rio Passa Cinco (SP). Trabalho de Conclusão de Curso. Rio Claro, UNESP.

Azevedo, T. S., 2003. Análise espaço temporal da dimensão fractal de matas ciliares na Alta Bacia do Rio Passa Cinco - Centro Leste do Estado de São Paulo. Dissertação (Mestrado) Rio Claro, UNESP.

CEPAGRI. Centro de Pesquisas Meteorológicas e Climáticas Aplicadas à Agricultura, 2017. Clima dos Municípios Paulistas. Disponível em: <http://www.cepagri.unicamp.br/outrasinformacoes/clima-dos-municipios-

paulistas.html>.Acesso em: 16. Jan. 2017.

De Biasi, M., 1992. A carta clinográfica: os métodos de representação e sua confecção. Revista do Departamento de Geografia 6, 4560.

Facincani, E. M., 2000. Morfotectônica da Depressão Periférica Paulista e Cuesta Basáltica: regiões de São Carlos, Rio Claro e Piracicaba, SP. Tese (Doutorado). Rio Claro, UNESP.

Filizola, H. F.; Almeida Filho, G. S.; Canil, K.; Souza, M. D.; Gomes, M. A. F., 2011. Controle dos processos erosivos lineares (ravinas e voçorocas) em áreas de solos arenosos. Circular Técnica 22, 1-7.

Godoy, D. F.; Hackspacher, P. C.; Guedes, S.; Hadler Neto, J. C., 2006. Reconhecimento da tectônica mesozoica-cenozoica na borda leste da Bacia do Paraná através da aplicação de traços de fissão em apatitas no Domo de Pitanga (sudoeste de Rio Claro, SP). Geociências 25, 151-164.

Hubp, J. I. L., 1988. Elementos de geomorfologia aplicada (métodos cartograficos), Universidad Nacional Autónoma de México, México.

IAC. Instituto Agronômico de Campinas, 1981. Levantamento pedológico semidetalhado do Estado de São Paulo - Quadrícula São Carlos SF-23-Y-A-I. Campinas, Escala 1:100.000.

IAC. Instituto Agronômico de Campinas, 2014 Solos do Estado de São Paulo. Disponível em: $<\mathrm{http} / / /$ www.iac.sp.gov.br/solossp/>. Acesso em: 16 jan. 2017.

IPT. Instituto de Pesquisas Tecnológicas, 1981a. Mapa Geológico do Estado de São Paulo. São Paulo.

IPT. Instituto de Pesquisas Tecnológicas - IPT, 1981b. Mapa Geomorfológico do Estado de São Paulo. São Paulo.

Lupinacci, C. M.; Andrade, R. V., 2017. A morfometria do relevo em área de transição Cuestas-Depressão: um estudo de caso. ENANPEGE 12, 11568-11576.

Paschoal, L.G.; Conceição, F. T.; Cunha, C. M. L., 2010. Utilização do ArcGIS 9.3 na elaboração de simbologias para mapeamentos geomorfológicos: uma aplicação na área do complexo argileiro de Santa Gertrudes/SP. Simpósio Nacional de Geomorfologia 8, 2010, 01-14.

Penteado, M. M., 1976. Geomorfologia do setor centro-ocidental da Depressão Periférica Paulista, Instituto de Geografia/Universidade de São Paulo, São Paulo. 
Perrotta, M. M. et al., 2005. Mapa Geológico do Estado de São Paulo. Escala 1:750.000. São Paulo.

Pinheiro, M. R.; Queiroz Neto, J. P., 2015. Neotectônica e evolução do relevo da região da Serra de São Pedro e do baixo Rio Piracicaba/Sudeste do Brasil. Revista Brasileira de Geomorfologia 16, 593-613.

Projeto RadamBrasil, 1983. Folhas SF23/24 Rio de Janeiro/Vitória, geologia, geomorfologia, pedologia, vegetação e uso potencial da terra, Rio de Janeiro.

Santos, M.; Ladeira, F. S. B., 2006. Tectonismo em perfis de alteração da Serra de Itaqueri (SP): análise através de indicadores cinemáticos de falhas. Geociências 25, 135-149.

Souza, T. A.; Oliveira, R. C., 2012. Avaliação da potencialidade de imagens tridimensionais em meio digital para o mapeamento geomorfológico. Revista Geonorte 2, 13481355.

Stefanuto, E. B; Lupinacci, C. M., 2016. Características morfoestruturais do relevo em setor de cuestas: um estudo em Analândia (SP). Revista Brasileira de Geografia Física 8, 1197 1211.

Tricart, J., 1965. Principes et méthodes de La géomorphologie, Masson, Paris.

Verstappen, H. T.; Zuidam, R. A. V., 1975. System of geomorphological survey, Manuel ITC Textbook, Netherlands.

Valente, R. O. A., 2001. Análise da estrutura da paisagem na Bacia do Rio Corumbataí, SP. Dissertação (Mestrado), Piracicaba, ESALQ.

Vieira, P. C., 1982. Hipótese sobre a origem da Depressão Periférica Paulista. Revista do Instituto Geológico 3, 61-67. 